\title{
Security, Violence, and Outlawed Martial Arts Groups in Timor-Leste
}

\author{
Janina Pawelz
}

\begin{abstract}
Martial arts groups in Timor-Leste have a nationwide reach and have offered a resource of physical and social engagement for youth and adults for several decades. Yet, their involvement in crime, politics, and violent clashes, and their notorious reputation as troublemakers posing a threat to security and peace, have caused the government to permanently ban three major groups. Based on intensive fieldwork and qualitative interviews with members and leaders of illegalized groups, this analysis explains why the young democracy's decision is not contributing to building peace. The three main findings from the interviews are that root causes of violence are not addressed by the ban, criminalization draws more people into illegality, and the positive aspects of these groups, which could potentially contribute to peace, are neglected.
\end{abstract}

Keywords violence, security, peacebuilding, martial arts, Timor-Leste

\section{Introduction}

Timor-Leste emerged from the ashes of war to become independent in 2002. The 24 years of Indonesian occupation were marked by violence, displacement and starvation, and about one-third of the East Timorese population lost their lives. The era of independence has brought liberation and new opportunities to the young democracy, yet the country continues to face major obstacles. Besides the challenges of nation building, democratization, decentralization, and overcoming four centuries of Portuguese colonization, peacebuilding remains the ultimate goal in the post-conflict period. In this regard, violence-prone groups, such as martial arts groups, are widely considered to be a major threat to peace. They played an important role during the crisis of 2006 that led to the breakdown of the state, and they are held responsible for numerous violent clashes between rival groups, the burning down of dozens of houses, and spreading a feeling of insecurity among the population. They are deeply entangled with the political 
arena and the security forces, and reportedly have been used for political intimidation, attacks on enemies, and self-defense of political parties (Scambary 2006; TLAVA 2009). Violence-prone groups challenging the legitimacy of the state are a common feature of post-conflict countries (see, for instance, Snyder 2000). Therefore, the measures taken to ensure effective control over these groups are of major importance. Repression is likely to be an easy first choice, but it holds tremendous potential for further aggravating the problem. The case of TimorLeste shows that peacebuilding measures need to be carefully designed in order to prevent violent backfiring.

This article presents the consequences of a fairly new regulation designed to reduce violence and martial arts activities in Timor-Leste. Acknowledging that one man's freedom fighter is another man's terrorist, it remains difficult to draw an objective line between violence-prone groups and civil society organizations. In the case of Timor-Leste, the regulation called for the disbandment of three martial arts groups and has sharply divided public opinion, ranging from a necessary move to ensure security in the country to a violation of the human right of freedom of association. The research underlying this article is based on interviews conducted in Timor-Leste in 2014 with leaders and members of martial arts groups, representatives of nongovernmental organizations (NGOs), youth workers, state representatives, and members of the Regulatory Commission of Martial Arts (KRAM); as well as on research findings from local and international NGOs, press releases, and newspaper articles. Major findings are that the regulation may halt martial arts activities and street fights, but it fails to address the root causes of violence, may push people into illegality and organized crime, and neglects positive aspects related to martial arts groups such as their social role in the community.

\section{Martial Arts Groups and Violence in Timor-Leste}

In the post-liberation period, violence by youth and martial arts groups has been a focus of the national and international news media, the Timorese government, and development aid organizations. While the Timorese government is concerned about stability and security in the country and faces the threat of becoming a "failed state," the international media fuels public fear with sensational headlines of rioting youth threatening the country's path to prosperity and peace. At the same time, several NGOs and development aid agencies are calling for more support for Timor-Leste's young generation (Plan Timor-Leste 2007).

The watershed event of the 2006 crisis drew much attention to Timor-Leste's youth and martial arts groups and evoked these contradistinctive views. The crisis started when members of Timor-Leste's military (F-FDTL), who were originally from the western part of the country, submitted a petition to top government 
leaders claiming that they were being discriminated against by soldiers from the eastern part. In early 2006, 549 soldiers were dismissed for desertion, and the situation escalated when a demonstration of the so-called petitioners and their civilian supporters, mostly unemployed youth, turned into a riot (Scambary 2009; International Crisis Group 2006). The violence spread quickly as more gangs and civilians got involved. In the end, the crisis caused an estimated 150,000 internally displaced persons due to destruction of their homes and property during the violence between the police, the military, and various martial arts groups. Within two months, up to 38 people died and 1,650 houses were destroyed (International Crisis Group 2008). Almost overnight, Timor-Leste's martial arts groups became notorious for daily clashes between rival groups, or between martial arts groups and international security forces-for stone-throwing, burning down houses, and committing homicide, and even for being "mobs-to-hire," since rumors held that martial arts groups were being paid and manipulated by political leaders (TLAVA 2009; Plan Timor-Leste 2007).

Timor-Leste is home to a huge array of social organizations, including martial arts groups. The common ground for martial arts groups is the practice of a particular form of sports, such as karate, pencak silat, judo, or taekwondo. They have complex histories dating back to the Indonesian occupation, were partly involved in the liberation struggle, and are politically and personally affiliated, creating a complex, nationwide network of alliances.

Martial arts groups can be found in all 13 districts of the country, with PSHT (Persaudaraan Setia Hati Terate) being the largest and most influential one with, by their own account, a total of 35,000 members across all thirteen districts (PSHT leader, Oct. 16, 2014). ${ }^{1}$ PSHT originated in Indonesia, just like their rival group Kera Sakti (IKS/Ikatan Kera Sakti). Both were introduced in Timor-Leste in the early 1980s; they practice the martial art called pencak silat, yet in two different styles. The group KORK (Kmanek Oan Rai Klaran) is originally from Timor and emerged around the same time as PSHT and Kera Sakti (Kera Sakti leader, Oct. $25,2014)$. Their histories are complex and some groups actively supported the independence movement by changing their names and participating politically in the clandestine front. For instance, PSHT changed its name to Fuan Domin and operated secretly to avoid repression by the Indonesian occupiers for their involvement in the political struggle for independence. Today Fuan Domin, like Kera Sakti's counterpart, Assosiasaun Joventude Apoiu Dezinvolvimentu (AJAD) and Padjajaran's group, Kombat, is part of the umbrella organization Klibur Organizasaun Rejistensia Nasional Timor Leste (KORENTIL) (Fuan Domin leader, Nov. 6, 2014).

PSHT, Kera Sakti, and KORK are well known for their rivalries and were banned in 2013 by a government regulation. There are still legal groups in Timor-Leste, including Pajajaran, Persisai Diri, Seruling Dewata, Rajawaliputih, Wushu (formerly Kungfu Master), that practice martial arts such as karate, 
kempo, taekwondo, shindo, and aikido. As opposed to the Indonesian original, the Timorese style of pencak silat is offensive and aggressive, rather than selfdefensive and awareness oriented (NGO leader, Oct. 9, 2014). It is important to note that PSHT, Kera Sakti, and KORK are considered to be heavily involved in violence, and these are the groups most often referred to when talking about "martial arts groups" in Timor-Leste.

There are official and informal affiliations among martial arts groups, political parties, politicians, and the security forces. In the majority of cases the links are based on personal, clandestine, and kinship alliances, as well as on family ties (Myrttinen 2010). The large percentage of martial arts group members in the police force has led to various problems, such as informing fellow martial arts members about a scheduled raid, taking sides during street fights leading to arbitrary arrests, and hence ineffectively solving community problems (NGO leader, Oct. 9, 2014). When then Prime Minister Xanana Gusmão ordered the members of the police (PNTL) to quit their martial arts groups in January 2014, 993 members (more specifically, 654 from PSHT, 243 from KORK, and 96 from Kera Sakti) declared their loyalty to the police force by officially surrendering their martial arts uniforms (Jornal Nacional Diario 2014). These numbers are evidence of massive infiltration of martial arts members into the police.

Although the bulk of group members consists of ordinary young men, high-ranking leaders are often well educated and hold high positions in the government (political leader, Sept. 26, 2014). High-ranking leaders, who are commonly in their forties, fifties or sixties, provide guidance, protection and patronage, and are sometimes said to have magical powers (Myrttinen 2010). Links between martial arts groups and politicians or political parties are often denied and remain fluid, informal, and tied to personal alliances. Nevertheless, martial arts groups are a major source of quick political mobilization, especially during election periods when the threat of political violence, possibly caused by political manipulation, rises. Martial arts groups also provide personal security for politicians during the campaign period (youth worker, Oct. 22, 2014). While most relationships remain secret, some are open secrets. In the elections of 2012 a new political party, KHUNTO, participated for the first time and only missed the three percent threshold by 150 votes. This surprisingly high level of support can be explained by its affiliation with the martial arts group KORK (Pawelz and Myrttinen 2012).

\section{The Decision to Ban PSHT, KORK, and Kera Sakti}

In 2008, the government of Timor-Leste passed a law on the Practice of Martial Arts in Timor-Leste. The first sentence of government law No. 10/2008 reads: "The practice of martial arts activities in Timor-Leste is of social and cultural 
importance for the population, especially among the young people, and its teaching also is a means of transmitting values and fundamental principles of conducts and characters [sic] of its practitioners and fans" (Government of Timor-Leste 2008). However, by 2013 opinion had changed drastically, as the Council of Ministers (in resolution No. 16/2013: Extinction of Martial Arts Groups) decided on "the extinction of the groups designated by PSHT, KORK, and KERAK SAKTI [sic], as well as a number of other measures designed at restoring public order and social harmony, which are threatened by the actions committed by these groups" (Council of Ministers 2013). How did the situation change between 2008 and 2013, prompting this drastic action?

Law No.10/2008 came into force on September 14, 2008. The preamble of the law drew attention to the "dangerous nature of some of the techniques used in the practice of Martial Arts" and an increase of violence and criminality as the reasons for this law, which aims to ensure "the principles of public order and respect for the rights, freedoms and guarantees of the citizens" (Government of Timor-Leste 2008). The aim of the law was to regulate existing martial arts groups and to "discourage the exercise of activities devoid of a proper legal framework," thus only allowing the practice of martial arts according to the rules made by the government. The effectiveness of the law for preventing violence related to martial arts was difficult to gauge as members could breach the regulation without consequences and cases were not formally processed (Belun 2014a).

On December 22, 2011, the Council of Ministers approved in an extraordinary meeting "measures to ensure public order and internal security of the country." This decision was made against the background of incidents involving martial arts groups which led to "serious disturbances, destruction of property and have killed and wounded people." In regard to the approaching elections in early 2012, the Council of Ministers decided to "suspend, until December 21,2012, the authorization to practice martial arts group activities that have lately proven to provoke unrest, violence and crime, including a ban on training and practice of martial arts, and the absolute obligation not to mobilize people to join the groups who practice martial arts" (Council of Ministers 2011).

Eventually the permanent ban on the three martial arts groups followed. On July 2, 2013, the government of Timor-Leste published a press release that explained that the authorities had been facilitating meetings aimed at obtaining commitment statements from martial arts groups, but these efforts had failed due to the lack of responsibility of some martial arts leaders. The press release went on to say that the latest occurrence of violent incidents, including serious disturbances, property destruction, injuries and deaths, had spread to foreign countries involving Timorese citizens abroad. For example, it referred to a recent clash that involved Timorese young men identified with martial arts groups studying abroad in Surabaya, Indonesia, leaving two dead (Tempo 2013).

It is noteworthy that a human rights NGO in Timor-Leste has criticized 
the ban as being invalid and a violation of human rights. The human rights NGO explained that the constitution of Timor-Leste guarantees the freedom of association unless the intention of the association is to promote violence. That means that a court has to decide whether martial arts groups are promoting violence and decide on further consequences. According to the NGO, the ban on the martial arts groups is not a law, but a quick decision of the council of ministers (NGO staff, Dec. 5, 2014).

\section{Consequences of the Ban: Three Findings}

Opinion on the banning of the three martial arts groups has been sharply divided. There is a consensus that the problem of violence and crime needs to be addressed, but views about causes and needed measures vary. On the one hand, most people interviewed agreed with the ban because it is a decision by the leaders of Timor-Leste and therefore has to be followed. Additionally, levels of violence have declined and fewer street fights disrupt public order (NGO staff, Nov. 31, 2014). According to a recent survey by the NGO Belun, 509 out of a total of 831 respondents (61.3\%) agreed that martial arts groups are of no benefit to communities, and $78 \%$ of their respondents declared that they absolutely supported the government's decision to ban PSHT, Kera Sakti, and KORK (Belun 2014b). On the other hand, a number of people, including researchers, representatives of local and international NGOs, religious institutions, and even some members of the Regulatory Commission of Martial Arts (KRAM), have voiced critical views that reflect careful analysis and alternative perspectives. They point to the weakness of political leadership, socioeconomic root causes, weak administrative power, and the failure of the state to protect its citizens. Most importantly, they perceive the ban as dismissive of the potentially positive role in society that martial arts groups could play in reaching and teaching neglected young people. While opinion is divided, many people report that the banning of the martial arts groups has been ineffective as members continue to practice despite the ban (youth worker, Feb. 20, 2014; Belun 2014b).

\section{Finding 1: Failed Targeting of Root Causes of Violence}

The ban on martial arts does not address the sources of youth violence in general as it only refers to the practice and training of martial arts by these three particular groups. Belun has called for a more holistic understanding of this issue, explaining that a ban is not effective when root causes are not targeted. Causes of violence have been identified as social jealousies due to unequal access to public goods and services, resources, and employment opportunities (Belun 2014b). Incidents of youth violence are easily mistaken as martial arts violence, though most causes of violent incidents have other origins. While the 
number of incidents of martial arts violence has decreased since the ban, youth violence in general has increased (Belun 2014a, 3). It is difficult to determine whether an incident of violence can be traced back to martial arts, as people have multiple identities, such as family, village, school, or a soccer club (NGO staff, Feb. 21, 2014). While the ban on wearing the typical uniforms that identify group members might decrease provocations that lead to violence, the ban fails to the address root causes and sources of fights, such as land disputes, domestic violence, social jealousies, inequality, and unemployment (Belun 2014a, 4; Bolitho 2013). James Scambary notes reasons why the ban might turn out to be ineffective:

You can stop the martial arts groups but you can't stop the communal fighting if you don't remove the source of it. So a lot of it is family stuff. It's just on the surface it appears to be martial arts groups because people align themselves with a group to protect themselves. (Bolitho 2013)

A priest explained that the root causes of violence are problems, such as land disputes, that are transferred from parents to their children who take it to school, the market, or to groups of friends who are activated in a move of solidarity:

When we gathered with leaders we discovered that martial arts groups are not the problem. The problems are [those of] individuals. It's not a group conflict. ...The bishop also realizes that the problem is not the young people but the political leaders. ... For the new generation the government doesn't care! (church member, Feb. 20, 2014)

Martial arts groups include members from all levels of society, including politicians, security forces, community leaders, as well as young and old, employed and unemployed. When it comes to martial arts violence, young men are the main perpetrators, and alcohol and drug abuse often fuel violent incidents (Belun 2014a). In the violent crisis of 2006, martial arts groups were heavily involved in violence and destruction of property. However, since then involvement in violence has decreased significantly. Interview respondents argue that the causes of the problems are not violent and delinquent behavior by youth, but political leaders who use and instrumentalize young people. Political manipulation and instrumentalization of youth was frequently mentioned when referring to martial arts violence. For instance:

Leaders switch from one political party to another. If there is a disagreement they leave one party and go to another party. They change their political identities according to their needs. And the leaders who change the position ask the youth to make problems with the other party they just left. (church member, Feb. 20, 2014) 
Both youth and martial arts groups are influenced by political parties. Leaders of martial arts groups are in political parties. When there is a campaign the group members come to provide security because their leader is involved. (NGO staff, Feb. 19, 2014)

In August 2013 there was a reported increase in violence marked by theft, murder and sexual assault, and a growing number of persons were recruited to organized crime. Most frequently recruited were government employees, taxi drivers, security guards on the border, airport security guards and personnel, and youth (Fundasaun Mahein 2013a; 2013b). The reason why many Timorese opt for organized crime is obvious for the NGO Fundasaun Mahein: "Timorese citizens of all backgrounds are turning towards organized crime in the midst of an economy that leaves them little hope for opportunity" (2013b, 2). Profits from the petroleum industry are high, but only a few people are benefitting while many Timorese live in poverty. The temptation to participate in criminal activities seems more lucrative and attractive compared to incentives for honest work:

The Timorese economy is stagnating and Timorese have fewer places to turn for career opportunities. With inflation rising, high unemployment, low salaries for government workers, and minimal government oversight of criminal activity, the temptation to participate in organized [crime] is too attractive for many Timorese to resist. (ibid., 3)

According to Fundasaun Mahein's research findings, the influence of criminal organizations will grow if these root causes are not dealt with:

As a result, as the economy falters it becomes increasingly easy for criminal organizations to recruit Timorese to work for them. If ordinary citizens face few options in this country, what incentive do they have to make an honest living when organized crime offers them far better pay? (ibid.)

\section{Finding 2: Fostering Illegality}

Despite its objective to contribute to peace in the country, the ban on martial arts groups does not target the root causes of violence. In fact, it could even contribute to the deterioration of the situation by fostering a path to crime and illegality. Unintended consequences include: illegalized groups go underground and are more difficult to confront and control; young people are pushed into illegality if they continue practicing; members may get involved in organized crime; and the practice of martial arts can be spread to new territories, including Indonesia, as members cross borders to practice and complete belt-class graduation.

Following the ban, the government failed to prepare alternative ways to integrate ex-members of martial arts groups into society, which made them very vulnerable to recruitment to other kinds of collectives, such as organized crime 
groups (NGO leader, Oct. 9, 2014). According to Fundasaun Mahein, the ban may have hampered martial arts activities, but incidents of violence and murders continued. The number of legitimate groups that youth could engage in was reduced while leaving large numbers of criminal groups, hence pushing youth into criminality.

While this effort has been largely successful in halting martial arts activity, it has done nothing to lower the overall rate of violence or illegal activity, seemingly displacing it instead of halting it. ... If they are not in martial arts gangs, Timorese youth are still being recruited by organized crime and divided into various groups to commit violent and illegal acts. (Fundasaun Mahein 2013a, 8)

Recently Fundasaun Mahein identified the sophisticated hierarchical structure of an organized crime network operating in Timor-Leste (ibid., 3-4). On top of the network there is an "intellectual" head who is responsible for analyzing the economy, politics, law and national security, and who orders and finances the criminal acts to be carried out. Below the intellectual are the "executive leaders" who coordinate the operations, including drug trafficking, transport of illegal goods, stealing and re-selling motorbikes, human trafficking and prostitution. The executive leaders command "operators" who are directly responsible for the successful implementation of schemes, and who recruit and organize the "execution teams." The executors are mainly Timorese youth who are "provided with drugs, transportation, weapons, and any other resources necessary to complete their assignments, which include theft, terrorizing the population, sexual assault, drug trafficking, and other violent acts." Fundasaun Mahein identified four execution teams that operate in Dili: Kibata, Monster, Dewa Mabuk, and Mager. One of my interviewees stated that banning the three groups only caused them to change into new types of organizations such as Kibata and other executions teams (NGO staff, Feb. 21, 2014).

A positive aspect of the ban, highlighted by Scambary, is that members are prohibited to wear their uniforms that had provoked and led to fights in the past (Bolitho 2013). Reportedly they still wear their uniforms on certain occasions, and especially in the rural areas it can be observed that youths wear t-shirts or necklaces with symbols that clearly indicate their affiliation. And it is reported that many members still participate in trainings, which are taking place at night in hidden places (church member, Feb. 20, 2014; NGO leader, Oct. 9, 2014; Suara Timor Lorosa'e 2014b).

Although the government decided to close them, there are still conflicts. In some places they meet in the night, sometimes controlled by the police, sometimes in a small village where the police don't know. Some martial arts members know about the law, but they continue. One factor is that they think it is not fair for them to be closed and discriminated [against] and that's why they continue. (NGO staff, Feb. 18, 2014) 
Additionally, some groups have transferred their martial arts activities to other places, such as the Oecussi enclave, to avoid prosecution, hence expanding their geographic reach and their level of sophistication (NGO leader, Oct. 9, 2014). Since the ban prohibits all martial arts activity in Timor-Leste, trainings and also the belt exams to attain full membership take place in Indonesia. In late 2014 the Timorese police caught hundreds of members of PSHT at the Indonesian border who were accused of "hasai sabuk" (going to take the exam) (Suara Timor Lorosa'e 2014a).

Wherever Timorese people live, martial arts groups also exist there! So the government thinks "ok, let's ban it." But now they are still hiding. The training is in a hidden place and sometimes they cross the border to have their exams in Indonesia, and Indonesia accepts it! For the sake of the future time bomb, they accept it! (NGO leader, Oct. 9, 2014)

\section{Finding 3: Failing to Recognize Positive Aspects of Martial Arts Groups}

By banning PSHT, Kera Sakti, and KORK the government failed to use existing structures that could contribute to building peace in the country. This includes the tight network structure and the immense outreach of these groups to the remotest areas which could enhance youth's social participation. On the one hand, there is a lack of outreach to rural youth and few options for youth to participate in society or develop good citizenship by getting involved in organizational structures. On the other hand, the consistent, well-developed structure of martial arts groups has been illegalized. In regard to peacebuilding, youth participation plays an important role (Goldstone 1991). According to interview respondents, the capacity of martial arts groups, with their positive curricula for their students, has been overlooked. Internally, all martial arts groups deploy codes of conduct and ethical discipline guidelines, including the value of nonviolence. For instance, members of PSHT used to meet three times a week to train and study their doctrine, which included aspects of civic education (PSHT leader, Dec. 8, 2014). Though there is an apparent lack of research on the curricula of these groups, there is the option of consulting the leaders and integrating nonviolent conflict management into their sports curricula (NGO staff, Feb. 21, 2014). This could include ensuring that their practices are those of a sporting organization and investing in a trained leadership that is capable of promoting positive values and morals.

Besides sports trainings the groups also support an internal network of mutual assistance. This includes, for instance, helping when someone gets sick, practical support for building a house, and financial support for weddings or funerals, and community projects (Kera Sakti leader, Oct. 25, 2014; PSHT leader, Dec. 8, 2014). This nationwide network, reaching across families, hamlets, districts, ethnic groups, and language barriers, appears to be a true definition of 
brotherhood, creating the sense of a large family and identity for members.

Although the inclusion of youth is of high importance in regard to peacebuilding, especially in post-war societies, the meaningful participation of youth in Timor-Leste is still not evident. Although elections are generally regarded as free and fair (Binsbergen et al. 2012), formal channels for voicing public opinion are limited. Outside of election periods, decision making and political and civic engagement seem to be limited to Dili, as "the period following elections reveals a politically disengaged public, which allegedly provides the elite with the opportunity to undertake a top-down approach ..." (CEPAD/Interpeace $2012,23)$. Data on youth participation reflects this point: The majority of youth (83\%) voted in the 2012 election, but few young people were politically active after the election period. Of the young persons who were surveyed (by Search for Common Ground), $75 \%$ of male and $68 \%$ of female respondents claimed to be "active" or "very active" in the 2012 presidential and parliamentary elections, but only $20 \%$ of all respondents (both male and female) continued to be politically active after the elections. ${ }^{2}$ In the past decade youth activism has declined due to disillusionment among youth, prompting Search for Common Ground to conclude that they "must continually seek new ways to keep youth engaged" (Search for Common Ground 2012, 23). With the banning of these martial arts groups, the existing structure to reach out to these youth has been lost. The divide between Dili and the district capitals, and between the district centers and the mountainous areas (foho) remains distinct, and so it is a major challenge to reach out to the youth living in rural areas.

In Dili there is much to do, but in the foho, what do you do? Young people still have energy, but there is nothing to do. Martial arts is there. That's why they join them! If the state [does] not provide options, then martial arts is a good answer to the question. Now the groups are shut down, it's the last option for the young people that is gone. (NGO staff, Feb. 21, 2014)

Martial arts groups have a nationwide reach with branches down to the district and village levels. For instance, PSHT is highly organized and hierarchically structured. On the top is the national president, followed by the second highest position, the secretary general. Each district has a district coordinator, followed by sub-district coordinators. The sub-districts are divided into rantings, the smallest unit, headed by the ranting coordinator (PSHT member, Oct. 13, 2014). Local leaders and the police used to work together with the leaders of the martial arts groups to discuss community problems and identify criminals. According to my interview respondents, this changed after the groups were banned as leaders refused to assist since they "don't exist anymore" (PSHT leaders, Nov. 10, 2014; Dec. 8, 2014).

In the case of Timor-Leste, martial arts groups could compensate for 
governance shortcomings and also create social space and social networks among citizens; they could also provide services. Similar groups commonly emerge in weak states where public or private institutions fail to provide channels for civic and political participation (Kassimir and Flanagan 2010). This also accords with Hagedorn's argument that violence-prone groups are social actors within poor communities with weak mechanisms of social control. He also pinpoints the crux of the matter: Violence-prone groups are more than a crime problem and they cannot be easily destroyed by suppression or repression, or eliminated by force (Hagedorn 2005, 163-164). Nevertheless, as elaborated by Nordås and Davenport (2013), repression is a common response of governments who feel threatened by their youthful population.

\section{Conclusion}

Martial arts groups are a common kind of collective in Timor-Leste, with a nationwide reach and tens of thousands of members. Due to their frequent involvement in violent clashes, the government decided to ban three of the major groups in 2013. While the objective of this action was to restore public order and social harmony, it failed to address important aspects of the situation. Three main findings based on interviews are that (1) the root causes of violence are complex and are not addressed by the ban, allowing for a continuation of violence; (2) new problems emerge as people are drawn into illegality; and (3) positive aspects of these groups are neglected and the exclusion of youth is deepened as the potential to reach out to rural youth is lost. The regulation banning the three martial arts groups is not an effective measure to build peace in the long term.

In the short term, the ban contributed to a decline of violent clashes and created a superficial atmosphere of peace in the hot spot bairros (NGO staff, Nov. 31, 2014). The data collected by Belun supports this: Of 1,356 monitored incidents of violence, from February 2012 to September 2013, only 22 were reported to be related to martial arts (Belun 2014, 5). A reason for the decline of violent incidents related to martial arts is that members no longer wear their uniforms or symbols that triggered clashes in the past. Leaders of the banned martial arts groups also ordered their members to stay calm and to obey the regulation in hope that the ban will be lifted in the future if they refrain from violence (PSHT leader, Nov. 1, 2014; IKS leader, Oct. 25, 2014). But Belun's data also show that the numbers of reported incidents of youth violence (not related to martial arts) went up while martial arts violence decreased. The reason could be a simple data collection problem: Conflict could now be labeled simply as fights between youth and not martial arts groups since, according to the regulation, those three martial arts groups do not exist anymore (Kera Sakti member, Oct.13, 2014). 
In the long term, lasting peace will not be achieved by banning these groups. The effectiveness of the regulation is not very visible as members continue to practice and recruit new members, and prosecution of violations is not consistent. Retrospectively, measures that have proven to be effective in reducing militancy and violent behavior of violence-prone groups include, for instance, the strategy of "cash, contracts, and cooptation." This illiberal peacebuilding strategy of "buying peace" is unconventional and not flawless, but it has proven to be an effective measure in Timor-Leste. Leaders of potentially violent groups have received cash payments, for instance, covered as "research grants" (political leader, Sept. 26, 2014); or they have received government contracts to carry out infrastructure projects, which provide employment for many martial arts group members (NGO staff, Dec. 5, 2014). Leaders are easily coopted by offering them prestigious positions. These positions range from ministers, state secretaries, and employees in ministries to high positions in the police command structure or in the foreign service (NGO staff, Dec. 5, 2014; political leader, Sept. 26, 2014). The International Crisis Group explains that "the increasingly wealthy state has bought off the threat once posed by most dissidents with an expensive cash benefits scheme and succeeded in engaging most veterans' voices in mainstream politics" (International Crisis Group 2011, 1). In 2008 the government began to implement cash transfer programs directed at veterans, who are organized in large groups and pose a potential threat of violence. It was a pragmatic decision to "buy peace" after the 2006 crisis, which can work successfully unless the oil (the financial basis for "buying peace") runs out or frustrated members of violenceprone groups, who haven't profited from the cash schemes, contracts or high positions, reorganize into new, potentially violent, groups (NGO staff, Oct. 9, 2014).

From a broader perspective, Timor-Leste has achieved much in only 12 years of independence. Building peace in a post-war country is a balancing act among several issues, including dealing directly with youth concerns, but also establishing effective government institutions, facilitating free and fair elections, strengthening the economy and eradicating poverty, while investing in the health and education of its people. So far the resilience of the Timorese people has been an underestimated factor, which raises hope for the future.

\section{Notes}

1. All interviews were conducted in Timor-Leste by the author in 2014. Names of the respondents are omitted to preserve confidentiality.

2. Based on self-assessment of survey respondents: "How do you rate your level of participation in the 2012 parliamentary and presidential elections?" very active; active; passive; very passive; or, can't say. To assess the post-election political activity, survey 
respondents were asked: "In addition to the elections, are you currently involved in political and/or leadership activities?" Survey conducted by Search for Common Ground (2012).

\section{References}

Belun. 2014a. Combatting Martial Arts Violence in Timor-Leste. Dili: Belun.

Belun. 2014b. Dynamics of Martial Arts related Conflict and Violence in Timor-Leste. Research Report. http://belun.tl/wp-content/uploads/2014/06/MA_ResearchReport_24-June-2014_FINAL.pdf (accessed December 3, 2014).

Binsbergen, Endie, Janina Pawelz, José Siqui, and Barry Wohl. 2012. "Final Report Parliamentary Elections 2012 Recommendations: Election Observer Report." Dili: Friendship Observer Mission. http://www.vrijoosttimor.nl/PDFs/FOM\%20 FINAL\%20REPORT.pdf (accessed July 20, 2014).

Bolitho, Sam. 2013. Martial Arts Club Ban Prompts Growing Concern in East Timor. Asia Pacific ABC Radio Australia, October 11. http://www.radioaustralia.net.au/ international/radio/program/asia-pacific/martial-arts-club-ban-prompts-growingconcern-in-east-timor/1203502 (accessed December 3, 2014).

CEPAD/Interpeace. 2012. "Valuing the Collective Sacrifice of Independence in the Consolidation of Democracy in Timor-Leste." National Working Group Report on the Priority Issue of Individual and Party Interests over the National Interests. TimorLeste: CEPAD/Interpeace.

Council of Ministers, Government of Timor-Leste. 2013. "Extraordinary Meeting of the Council of Ministers on 2 July 2013.” Press Release. Timor-Leste: Council of Ministers. http://timor-leste.gov.tl/?p=8485\&lang=en (accessed December 3, 2014).

Fundasaun Mahein. 2013a. “The New Types of Organized Criminal Operations in TimorLeste.” Mahein's Voice Report 60. http://www.fundasaunmahein.org/wp-content/ uploads/2013/10/MNL_Nu.60_03102013_Criminal-Organizedpdf.pdf (accessed December 3, 2014).

Fundasaun Mahein. 2013b. "Krime Organizadu: Rekrutamentu Ba Ema Sivil Ho Numeiru Boot." Comentariu Nain 11. http://www.fundasaunmahein.org/2013/08/15/organizedcrime-increases-civilian-recruitment/ (accessed December 3, 2014).

Goldstone, Jack. 1991. Revolution and Rebellion in the Early Modern World. Berkeley: University of California Press.

Government of Timor-Leste. 2008. Lei Ba Arte Marciais. No. 10/2008. Dili: Government of Timor-Leste.

Hagedorn, John. 2005. “The Global Impact of Gangs.” Journal of Contemporary Criminal Justice 21 (2): 153-169.

International Crisis Group. 2006. Resolving Timor-Leste's Crisis. Asia Report No. 120. Jakarta and Brussels: International Crisis Group.

International Crisis Group. 2008. Timor-Leste’s Displacement Crisis. Asia Report No. 148. Jakarta and Brussels: International Crisis Group.

International Crisis Group. 2011. Timor-Leste's Veterans: An Unfinished Struggle? Asia Briefing No. 129. Dili, Jakarta and Brussels: International Crisis Group.

Jornal Nacional Diario. 2014. "Membrus PNTL 993 Entrega Atributu Artemarsiais." 
January 16. http://www.jndiario.com/2014/01/16/membrus-pntl-993-entregaatributu-artemarsiais/ (accessed December 3, 2014).

Kassimir, Ronald, and Constance Flanagan. 2010. "Youth Civic Engagement in the Developing World: Challenges and Opportunities." In Handbook of Research on Civic Engagement in Youth, eds. Lonnie R. Sherrod, Judith Torney-Purta, and Constance A. Flanagan. Hoboken, NJ, USA: John Wiley \& Sons, Inc., 91-113.

Myrttinen, Henri. 2010. "Histories of Violence, States of Denial - Militias, Martial Arts and Masculinity in Timor-Leste." PhD diss., University of Kwazulu-Natal.

Nordås, Ragnhild, and Christian Davenport. 2013. "Fight the Youth: Youth Bulges and State Repression.” American Journal of Political Science 57 (4): 926-940.

Pawelz, Janina, and Henri Myrttinen. 2012. "Wahlen in Timor-Leste: Feuerprobe für Sicherheit und Konsolidierung." GIGA Focus Asien 7/2012. Hamburg: GIGA German Institute of Global and Area Studies.

Plan Timor-Leste. 2007. Like Stepping Stones in the River: Youth Perspectives on the Crisis in Timor-Leste. Dili: Plan Timor-Leste.

Scambary, James. 2006. "A Survey of Gangs and Youth Groups in Timor-Leste." http:// www.etan.org/etanpdf/2006/Report_Youth_Gangs_in_Dili.pdf (accessed February 19, 2015).

Scambary, James. 2009. "Anatomy of a Conflict: The 2006-2007 Communal Violence in East Timor." Conflict, Security \& Development 9 (2): 265-288.

Scambary, James. 2013. "Informal Security Groups and Social Movements." Politics of Timor-Leste: Democratic Consolidation after Intervention, eds. Michael Leach and Damien Kingsbury. New York: Cornell University Press, 203-213.

Search for Common Ground. 2012. Youth, Democracy and Peacebuilding in Timor-Leste: A Joint Baseline Survey. https://www.sfcg.org/wp-content/uploads/2014/09/SFCG_ YEPS_DAME-Baseline-Report-_FINAL-publication.pdf (accessed February 11, 2015).

Snyder, Jack L. 2000. From Voting to Violence: Democratization and Nationalist Conflict. New York: Norton.

Suara Timor Lorosae. 2014a. "PNTL Kaptura PSHT 122 Hasai Sabuk Iha Indonesia." Suara Timor Lorosa'e, November 24. http://suara-timor-lorosae.com/pntl-kaptura-psht-122hasai-sabuk-iha-indonesia/\#sthash.EI4n9uci.dpuf (accessed December 3, 2014).

Suara Timor Lorosa'e. 2014b. "Deskonfia PSHT Kontinua Eziste, Faculto: Rezolve Problema Artemarsiais ho Kauza Laos Feitu." Suara Timor Lorosa'e, December 2. http://suaratimor-lorosae.com/deskonfia-psht-kontinua-eziste-faculto-rezolve-problemaartemarsiais-ho-kauza-laos-feitu/ (accessed December 3, 2014).

Tempo. 2013. "Dua Mahasiswa Timor Leste Tewas Dibacok.” October 9. http://www.tempo. co/read/news/2013/10/09/058520500/Dua-Mahasiswa-Timor-Leste-Tewas-Dibacok (accessed December 3, 2014).

TLAVA. 2009. Groups, Gangs, and Armed Violence in Timor-Leste. Timor-Leste Armed Violence Assessment, Issue Brief 2. Geneva: Small Arms Survey, Austcare.

Janina Pawelz is currently a doctoral student at the GIGA German Institute of Global and Area Studies in Hamburg, Germany. Her research interests are violence-prone groups, gangs, non-state 
actors, youth, youth violence, and political participation in Southeast Asia and the Caribbean. E-mail: janina.pawelz@giga-hamburg.de 